\title{
MECHANICAL PROPERTIES OF CASTOR BEANS SUBJECT TO DIFFERENT DRYING TEMPERATURES AIMING TO DISRUPT THE BEAN COAT
}

\author{
ADRIANO C. BASTOS ${ }^{1}$, ANTONIO C. DE O. FERRAZ ${ }^{2}$
}

\begin{abstract}
In castor oil extraction process, the bean coat is abrasive to the equipment and releases substances that modify the oil color, reducing its quality. A potential solution would be to run the extraction by compressing only the endosperm. Due to lack of information, the objective of this study was to evaluate the influence of forced air drying at $40,60,80$ and $100{ }^{\circ} \mathrm{C}$ and farmyard drying, in the mechanical properties of the beans, aiming to break the bean coat. Castor beans were subjected to compression tests, in two perpendicular directions, at a strain rate of $0.6 \mathrm{~mm} . \mathrm{s}-1$. Average values of force, deformation energy, strain, all at rupture, and stiffness were used to evaluate the effects of dehydration. It was observed that the heat treatments did not alter the mechanical properties of castor beans, the strain and stiffness values discriminate the differences between the directions and had the lowest coefficients of variation. It was concluded that forced air drying, more costly than farmyard drying, does not bring benefits to the decortication. However, regardless the heat treatment used, the mechanical stress lengthwise is the most suitable to promote decortication.
\end{abstract}

KEYS-WORDS: conditioning, threshing, decortication, compression.

\section{PROPRIEDADES MECÂNICAS DOS GRÃOS DE MAMONA SUBMETIDOS A DIFERENTES TEMPERATURAS DE SECAGEM A VISANDO A RUPTURA DO TEGUMENTO}

RESUMO: No processo de extração do óleo de mamona, o tegumento libera substâncias que modificam a coloração do óleo, reduzindo a qualidade, e causa abrasão nos equipamentos. Potencialmente, uma solução para esse problema seria executar a extração prensando somente o endosperma. Devido à carência de informações, o objetivo deste trabalho foi avaliar a influência da secagem com ar forçado a 40;60;80 e $100^{\circ} \mathrm{C}$ e secagem em terreiro, nas propriedades mecânicas dos grãos, visando ruptura do tegumento. Grãos de mamona foram submetidos a ensaios de compressão, em duas direções perpendiculares, com taxa de deformação de $0,6 \mathrm{~mm} \cdot \mathrm{s}^{-1}$. Valores médios da força, energia de deformação, deformação específica, todos na ruptura, e rigidez foram utilizados para a avaliação dos efeitos da secagem. Observou-se que, nas condições consideradas, os tratamentos térmicos não alteraram as propriedades mecânicas dos grãos de mamona e que os valores de deformação específica e rigidez discriminaram as diferenças entre as direções e apresentaram os menores coeficientes de variação. Concluiu-se que a secagem com ar forçado, mais oneroso que a secagem no terreiro, não traz benefícios à decorticação. No entanto, independentemente do tratamento térmico, a solicitação mecânica do grão na direção longitudinal é a mais indicada para promover a decorticação.

PALAVRAS-CHAVE: condicionamento, debulha, decorticação, compressão.

\section{INTRODUCTION}

The castor plant (Ricinus communis L.) is an oil crop of economic and social importance in Brazil, from whose grains oil with excellent properties is extracted. Generally, the industry uses hot pressing of the whole grains and due to the high abrasion of the bean coat or shell, the life of the extraction equipment is reduced, and accordingly, an undesirable migration of the pigment from the

\footnotetext{
${ }^{1}$ Eng $^{\circ}$ Agrícola, Mestre em Engenharia Agrícola: adriano.c.bastos@ gmail.com

${ }^{2}$ Eng $^{\mathbf{o}}$ Agrícola, Prof. Livre-Docente, Faculdade de Engenharia Agrícola- FEAGRI / UNICAMP, Campinas - SP: (19) 3521-1058, carlos@ feagri.unicamp.br
}

Recebido pelo Conselho Editorial em: 2-6-2011

Aprovado pelo Conselho Editorial em: 13-10-2013 
bean coat into the oil occurs. For these reasons, the extraction of oil by compressing only the endosperm without the bean coat, or part of it, is advantageous since it allows obtaining oils with lighter coloring, eliminates most of the abrasion problems, increases the extraction efficiency, promotes greater oil recovery and reduces energy requirements (RITTNER, 1996). However, in Brazil there are no decortication machines for castor beans. It is known that for the proper design of a huller, which strongly interacts with the product, it is necessary to know its physical and mechanical properties (MOHSENIN, 1986). Under this perspective, several investigations were conducted aiming the decortication of agricultural products considering the mechanical properties thereof (PLIESTIC et al, 2006; ARAÚJO \& FERRAZ, 2006; SIRISOMBOON et al (2007); ARAÚJO \& FERRAZ, 2008). Most often, a good performance in decortication requires prior conditioning of the product to properly modify some of its properties. GONELI et al. (2008) and GONELI et al. (2011) point out that dehydration significantly alters the physical properties of castor fruits, such as density, porosity and volume, being instrumental in the design of equipment and industrialization of grains. RIBEIRO et al. (2007) found that the maximum force and strain modulus for soybeans decrease with increasing water content. Evidence of anisotropic behavior was reported by RESENDE et al. (2007) at compressing beans in three mutually perpendicular directions. Despite the increased attention that the culture of castor beans has received from researchers and the Brazilian government, the work hitherto published is not aimed at post-harvest and processing of grains and their interactions with the oil quality. The work of OLAOYE (2000) and, more recently, GONELI (2008), represent efforts in investigating properties of castor beans, but are not targeted at decortication. The rupture force and corresponding strain, deformation energy and stifness are important mechanical parameters and can provide support for a decortication strategy. In this work, these parameters were used to evaluate the response of castor beans to various drying conditions. .

\section{MATERIALS AND METHODS}

The castor fruits used were produced at the Central North Pole of the Paulista Agency of Agribusiness Technology (APTA), located in the city of Pindorama - SP. Bunches of castor fruits 'AL Guarany 2002', early ripened, harvested and detached from the clusters manually, were transported to the UNICAMP Agricultural Engineering College where, on the same day, the green color fruits were separated from the dark colored ones. Only dark colored fruits were used. The initial water content of the fruit was determined after 24 hours at $4{ }^{\circ} \mathrm{C} \pm 0.4{ }^{\circ} \mathrm{C}$ and $75 \%$ relative humidity storage using the gravimetric method and forced air oven (model 320-SE FANEM ${ }^{\circledR}$ ) at the temperature of $105 \pm 1{ }^{\circ} \mathrm{C}$, until constant weight, with five repetitions (BRAZIL, 2009). The harvest of the fruits used in the experiment was done in May and July 2010, from the same planting area.

CASTOR FRUITS DRYING. Drying runs were performed in the Drying Laboratory ( UNICAMP Agricultural Engineering College) using a conjugate Convective Dryer perpendicular and/or parallel to the drying bed flow, which consists of a drying chamber with twenty drawers arranged in two columns, ventilation systems, heating system using electric resistances, air flow and temperature control system. In each repetition, the castor fruits were placed on a tray in number enough to fill it out and form a uniform layer, with an average weight of $636.39 \mathrm{~g} \pm 57.41 \mathrm{~g}$. Drying with 4 repetitions of each treatment was conducted with air temperatures of $40,60,80$ and $100{ }^{\circ} \mathrm{C}$, variation of $\pm 4{ }^{\circ} \mathrm{C}$ and average air speed of $0.9 \mathrm{~m} \mathrm{~s}^{-1}$. The recording of relative humidity and room temperature values was performed by a thermo hygrograph (model TH 508, CIBRAPAM ${ }^{\circledR}$ ).. The monitoring of water loss during drying was performed by weighing the tray, using an analytical scale with a resolution of $0.01 \mathrm{~g}$ (model SL-3000, SCIENTECH ${ }^{\circledR}$ ), at intervals of 15 minutes. We conducted tumbling of the fruit in the tray every 30 minutes. Drying was stopped when the water content of the grains was calculated between 4 and $8 \%(\mathrm{db})$, indicated by the final weight of the tray with the product. This estimate was performed through the initial moisture content of the fruit and considering only the water loss and constant dry mass. After drying, the castor fruits were threshed manually. Additionally, farmyard drying was performed on concrete floor, conventionally 
employed by producers, and used as the control treatment. The final water content of the grains after each drying treatment was determined by the gravimetric method (BRAZIL, 2009). After drying and threshing, grains were subjected to compression tests.

COMPRESSION TESTS. For mechanical testing a universal testing machine (model TA 500 Texture Analyser, LLOYD Instruments ${ }^{\odot}$ ) was used, from the Laboratory of Mechanical Properties of Biological Materials, UNICAMP Agricultural Engineering College. The grain test was conducted at a strain rate of $0.6 \mathrm{~mm} \mathrm{~s}^{-1}$ in two perpendicular directions, width and length (Figure 1), with rigid, flat and parallel plates with 15 repetitions for each direction and four repetitions for each drying treatment. The initial grain size in the direction of the load application was measured with a digital caliper (model 727-2001, STARRETT ${ }^{\circledR}$ ) with a resolution of $0.01 \mathrm{~mm}$. Preliminary tests indicated achieving the maximum strain of $2.50 \mathrm{~mm}$ for length and $2.00 \mathrm{~mm}$ in width, sufficient to promote application beyond the rupture of the bean coat. For this reason they were adopted for all tests. For each test the force-deformation curve up to breakage of the bean coat was obtained, identified by a sudden reduction in compressive force. From the curve, the maximum force, deformation energy to maximum force, strain and stiffness were determined (MOHSENIN, 1986; OLAOYE, 2000).

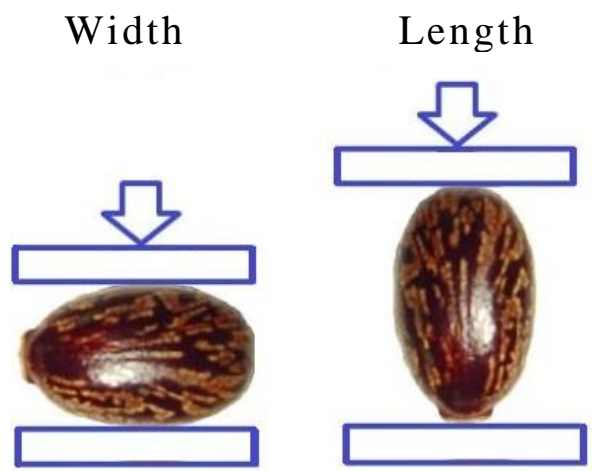

FIGURE 1. Castor bean positioning illustration for compression in two perpendicular directions.

The energy required for the rupture of the bean coat of castor beans was obtained by calculating the area under the force-deformation curve up to the moment of rupture, using the software NEXYGEN 3.0 by Lloyd Instruments ${ }^{\circledR}$. The maximum force and the corresponding strain were read from the force-deformation curves. Stiffness was calculated as the ratio between the maximum force and corresponding strain (GONELI, 2008).

In order to analyze the values obtained in the compression tests at different drying treatments, a randomized blocks statistical design was used. Analysis of variance was performed followed by mean comparisons between treatments and directions using the Duncan test $(\mathrm{p}<0.05)$, with the aid of the statistical computational package SAS 9.0 from the SAS Institute Inc. ${ }^{\circ}$.

\section{RESULTS AND DISCUSSION}

DRYING CASTOR FRUITS. The average initial moisture of the fruits for the May batch was $25.93 \%(\mathrm{db})$ and $21.79 \%(\mathrm{db})$ for the July batch, with coefficients of variation of $22.63 \%$ and $26.22 \%$, respectively. The beans, in turn, had average initial moisture content of $12.35 \%(\mathrm{db})$ for the May batch and $11.39 \%(\mathrm{db})$ for the July batch with coefficients of variation of $17.30 \%$ and $7.55 \%$, respectively. Drying times had higher variation in treatments at temperatures of 40 and 60 ${ }^{\circ} \mathrm{C}$. The drying time at $40{ }^{\circ} \mathrm{C}$ ranged from 165 to 225 minutes and for $60{ }^{\circ} \mathrm{C}$, it ranged from 60 to 105 minutes. For drying treatments with temperatures of 80 to $100{ }^{\circ} \mathrm{C}$, the drying times showed no variation, consisting of 60 minutes for the $80^{\circ} \mathrm{C}$ treatment and 45 minutes for the $100^{\circ} \mathrm{C}$ treatment. It took 31 hours and 55 minutes to complete farmyard drying of the fruits.

Table 1 shows the beans average water content after drying. Farmyard treatment had the lowest variability of water content since its slower drying process allows homogenization. Forced 
air drying showed high variability of the final water content values, with a coefficient of variation between 16.46 and $23.89 \%$, even turning over the samples during drying. The variability of the water content may have affected the mechanical properties of the beans. However, it is difficult to control the water losses during drying for small samples with high initial moisture content variability, especially using high drying temperatures. The final water content of the grains ranged between 4.66 and $7.79 \%(\mathrm{db})$, with higher temperatures resulting in lower water content, due to the high drying rates and difficulty in controlling the water content. The average final water content of all the drying treatments was of $6.60 \%(\mathrm{db})$ with a coefficient of variation of $27.36 \%$.

TABLE 1. Average water content of the beans after drying.

\begin{tabular}{llll}
\hline Drying treatment & Number of samples & $\begin{array}{l}\text { Average water contentCoefficient of variation } \\
(\% \mathbf{d . b})\end{array}$ \\
\hline Farmyard & 5 & 5.55 & 7.19 \\
$40^{\circ} \mathrm{C}$ & 20 & 7.78 & 16.46 \\
$60^{\circ} \mathrm{C}$ & 20 & 7.79 & 23.89 \\
$80^{\circ} \mathrm{C}$ & 20 & 6.15 & 18.03 \\
$100^{\circ} \mathrm{C}$ & 20 & 4.66 & 19.43 \\
Average & 85 & 6.60 & 27.36 \\
\hline
\end{tabular}

COMPRESSION TEST. Force-deformation Curves. The general appearance of characteristic curves obtained from compression tests after drying are illustrated in Figure 2. The biological yielding was not observed, and for both directions rupture was similar to that of fragile materials such as sunflower seeds (GUPTA \& DAS, 2000).

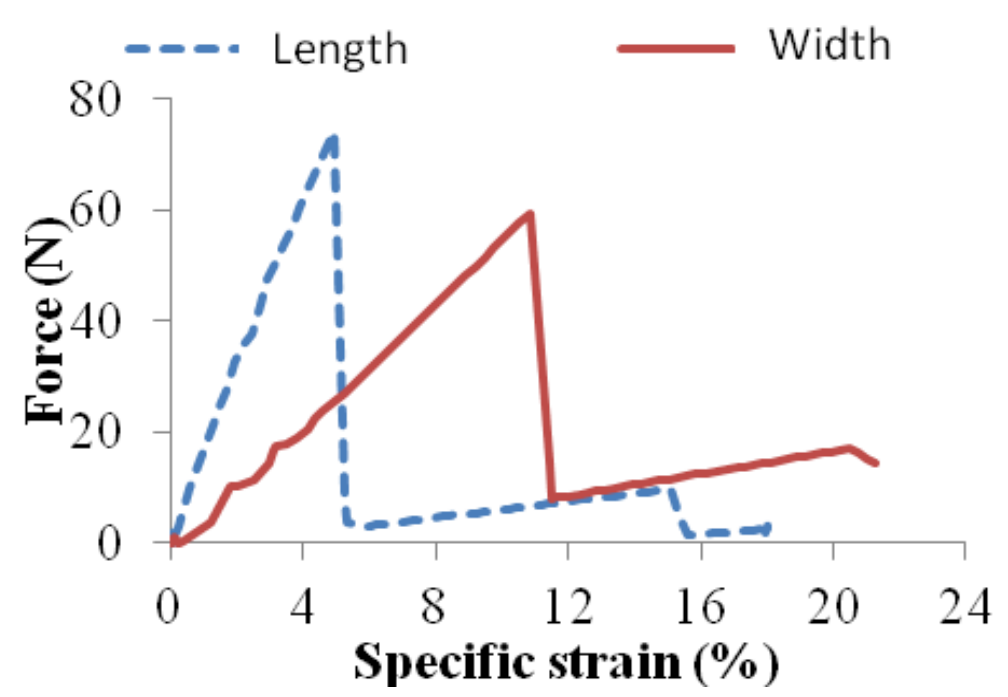

FIGURE 2. Characteristic castor beans compression force-strain curves in two perpendicular directions after drying treatment.

Maximum rupture force. Table 2 shows the average values of the maximum rupture force of the bean coat for each heat treatment obtained after compression tests for the two perpendicular directions. 
TABLE 2. Rupture force average values $(\mathrm{N})$ obtained in compression tests length and widthwise with respective coefficients of variation $(\mathrm{CV})$.

\begin{tabular}{|c|c|c|c|c|}
\hline \multirow[t]{2}{*}{ Drying treatment } & \multicolumn{4}{|c|}{ Direction } \\
\hline & Length & $\mathrm{CV}(\%)$ & Width & $\mathrm{CV}(\%)$ \\
\hline Farmyard & $\begin{array}{l}63.11 \\
A / b\end{array}$ & 16.01 & $\begin{array}{l}70.02 \\
\mathrm{~A} / \mathrm{a}\end{array}$ & 21.39 \\
\hline $40^{\circ} \mathrm{C}$ & $\begin{array}{l}59.68 \\
\mathrm{AB} / \mathrm{a}\end{array}$ & 18.81 & $\begin{array}{l}58.46 \\
\mathrm{~B} / \mathrm{a}\end{array}$ & 24.10 \\
\hline $60^{\circ} \mathrm{C}$ & $\begin{array}{l}59.23 \\
\mathrm{BC} / \mathrm{a}\end{array}$ & 19.71 & $\begin{array}{l}59.48 \\
\mathrm{~B} / \mathrm{a}\end{array}$ & 20.21 \\
\hline $80^{\circ} \mathrm{C}$ & $\begin{array}{l}56.96 \\
\mathrm{BC} / \mathrm{b}\end{array}$ & 15.41 & $\begin{array}{l}68.55 \\
\mathrm{~A} / \mathrm{a}\end{array}$ & 21.21 \\
\hline $100^{\circ} \mathrm{C}$ & $\begin{array}{l}55.52 \\
\mathrm{C} / \mathrm{b}\end{array}$ & 18.88 & $\begin{array}{l}66.91 \\
\mathrm{~A} / \mathrm{a}\end{array}$ & 22.75 \\
\hline Global average & 58.90 & 18.25 & 64.68 & 23.05 \\
\hline
\end{tabular}

Averages followed by the same capital letter in the column do not differ statistically from each other (Duncan, $\mathrm{p}<0.05$ ). Averages followed by the same letter in the line do not differ statistically from each other (Duncan, $\mathrm{p}<0.05$ ).

It is observed that the highest average value of the maximum force was $70.02 \mathrm{~N}$, along the width of the grain, for farmyard drying. The force values to rupture the bean coat are relatively low compared to $700 \mathrm{~N}$ needed to break the hazel nut (PLIESTIC et al., 2006), but are equivalent to those obtained by ARAUJO \& FERRAZ (2008) for cashew nuts and by SIRISOMBOON et al. (2007) for jatropha curcas beans.

The variation of the average maximum force value showed no clear trend associated with different drying temperatures. It was shown, however, that farmyard and $100{ }^{\circ} \mathrm{C}$ treatments lengthwise were significantly different, which does not occur widthwise. It was also observed by comparing the variations between length and width, in the same treatment, that the average maximum force did not discriminate for treatments 40, 60 and $80{ }^{\circ} \mathrm{C}$ any possible anisotropic behavior. Comparing the overall averages for all treatments, the value of the maximum force was higher along the width. GUPTA \& DAS (2000) also observed higher values of maximum force in the length or vertical direction for sunflower beans.

Deformation energy. Table 3 shows the average values of deformation energy until rupture of the bean coat, length and widthwise, for the drying treatments.

TABLE 3. Average strain energy to rupture ( $\mathrm{J})$ values from compression tests, length and widthwise, and respective coefficients of variation $(\mathrm{CV})$.

\begin{tabular}{|c|c|c|c|c|}
\hline \multirow{2}{*}{ Drying treatment } & \multicolumn{4}{|c|}{ Direction } \\
\hline & Length & $\mathrm{CV}(\%)$ & Width & $\mathrm{CV}(\%)$ \\
\hline Farmyard & $\begin{array}{l}0.0202 \\
\mathrm{~A} / \mathrm{b}\end{array}$ & 28.97 & $\begin{array}{l}0.0350 \\
\mathrm{~A} / \mathrm{a}\end{array}$ & 36.04 \\
\hline $40^{\circ} \mathrm{C}$ & $\begin{array}{l}0.0205 \\
\mathrm{~A} / \mathrm{b}\end{array}$ & 35.26 & $\begin{array}{l}0.0281 \\
\mathrm{~B} / \mathrm{a} \\
\end{array}$ & 41.56 \\
\hline $60^{\circ} \mathrm{C}$ & $\begin{array}{l}0.0204 \\
\mathrm{~A} / \mathrm{b}\end{array}$ & 39.58 & $\begin{array}{l}0.0290 \\
\mathrm{~B} / \mathrm{a}\end{array}$ & 32.67 \\
\hline $80^{\circ} \mathrm{C}$ & $\begin{array}{l}0.0180 \\
\mathrm{AB} / \mathrm{b}\end{array}$ & 32.30 & $\begin{array}{l}0.0365 \\
\mathrm{~A} / \mathrm{a}\end{array}$ & 33.87 \\
\hline $100^{\circ} \mathrm{C}$ & $\begin{array}{l}0.0169 \\
\mathrm{~B} / \mathrm{b}\end{array}$ & 34.00 & $\begin{array}{l}0.0337 \\
\mathrm{~A} / \mathrm{a}\end{array}$ & 38.59 \\
\hline Average & 0.0192 & 35.07 & 0.0325 & 37.81 \\
\hline
\end{tabular}


Similarly to the behavior of the average values of maximum force, the strain energy showed no trend associated to the increase of the drying air temperature. The coefficients of variation increased indicating variability in force-deformation relationship to achieve maximum force. Because of this high variability, strain energy may not be a good parameter for decortication. On the other hand, strain energy was effective to discriminate the differences in behavior between length and width, because for all treatments strain energy was significantly lower lengthwise. GONELI (2008) obtained values of castor bean coat deformation energy till rupture thicknesswise close to those found in this work, between 0.0256 and $0.0477 \mathrm{~J}$ for water contents between 8-66 \%

Rupture strain. Table 4 shows average values of rupture strain of the bean coat length and widthwise for the drying treatments.

TABLE 4. Strain average values (\%) at rupture force from compression tests width and lengthwise and corresponding coefficients of variation.

\begin{tabular}{|c|c|c|c|c|}
\hline \multirow{2}{*}{ Drying treatment } & \multicolumn{4}{|l|}{ Direction } \\
\hline & Length & $\mathrm{CV}(\%)$ & Width & $\mathrm{CV}(\%)$ \\
\hline Farmyard & $\begin{array}{l}4,37 \\
\mathrm{AB} / \mathrm{b}\end{array}$ & 16,77 & $\begin{array}{l}10,39 \\
\mathrm{ABC} / \mathrm{a}\end{array}$ & 18,31 \\
\hline $40^{\circ} \mathrm{C}$ & $\begin{array}{l}4,43 \\
\mathrm{AB} / \mathrm{b}\end{array}$ & 22,11 & $\begin{array}{l}9,70 \\
\mathrm{C} / \mathrm{a} \\
\end{array}$ & 22,82 \\
\hline $60^{\circ} \mathrm{C}$ & $\begin{array}{l}4,48 \\
\mathrm{~A} / \mathrm{b}\end{array}$ & 37,29 & $\begin{array}{l}10,21 \\
\mathrm{BC} / \mathrm{a}\end{array}$ & 16,99 \\
\hline $80^{\circ} \mathrm{C}$ & $\begin{array}{l}4,15 \\
\mathrm{AB} / \mathrm{b}\end{array}$ & 20,84 & $\begin{array}{l}11,10 \\
\mathrm{~A} / \mathrm{a}\end{array}$ & 17,68 \\
\hline $100^{\circ} \mathrm{C}$ & $\begin{array}{l}4,03 \\
\mathrm{~B} / \mathrm{b}\end{array}$ & 21,42 & $\begin{array}{l}10,54 \\
\mathrm{AB} / \mathrm{a}\end{array}$ & 22,69 \\
\hline Average & 4,29 & 25,19 & 10,38 & 20,12 \\
\hline
\end{tabular}

Averages followed by the same capital letter in the column do not differ statistically from each other (Duncan, $p<0.05$ ). Averages followed by the same letter in the line do not differ statistically from each other (Duncan, $\mathrm{p}<0.05$ ).

The average strain values obtained show the difference between width and lengthwise force application and are able discriminated anisotropic behavior for all treatments. However, similar to maximum force and deformation energy, they show no differences between drying treatments. The average strain value to rupture the bean coat was $58.67 \%$ less lengthwise. This shows that the rupture of the bean coat in this direction may result in less damage to the endosperm. The coefficients of variation are within an acceptable range for biological materials, except the too high a value of $37.29 \%$ for the $60{ }^{\circ} \mathrm{C}$ treatment, for reasons beyond our understanding. This fact was observed in sunflower beans by GUPTA \& DAS (1999). The strain values reported lengthwise show that only the $100{ }^{\circ} \mathrm{C}$ treatment differed statistically from the others, this being the lowest value presented. Despite showing statistical difference, this difference of $0.45 \%$ in strain between treatments is negligible in machine design, due to numerous factors. Widthwise, the 40 and $80{ }^{\circ} \mathrm{C}$ treatments were statistically different from each other, with the highest and lowest values. This difference of $1.4 \%$ in strain values between these drying treatments can be significant in grading material for decortication since dependency on the average sizes, may cause endosperm rupture.

In the castor bean radiography (Figure 3), showing average dimensions, it is observed that lengthwise and around the caruncle there is a gap between the endosperm and bean coat. This gap was estimated to be $0.21 \mathrm{~mm}$ or equivalent to $1.43 \%$ of the length.. Widthwise, a wider gap is observed, estimated at $0.38 \mathrm{~mm}$ or corresponding to $4.2 \%$ of the original width. These values are 34 $\%$ and $41 \%$ lower than the strain averages values found length and widthwise, respectively, and show that the endosperm is compressed before rupture occurs. Therefore, the resistance of the endosperm contributes to the values of maximum rupture strength of the bean coat. The average strain values, regardless of the heat treatment, were $4.29 \%$ for the length direction and $10.38 \%$ for 
the width direction. The value of the strain to reach rupture, regardless of the direction, can be reduced if a high strain rate is applied, due to the viscoelastic behavior of the grain (ARAÚJO \& FERRAZ, 2006). However, this does not guarantee fully disruption of the bean coat and separation from the endosperm.

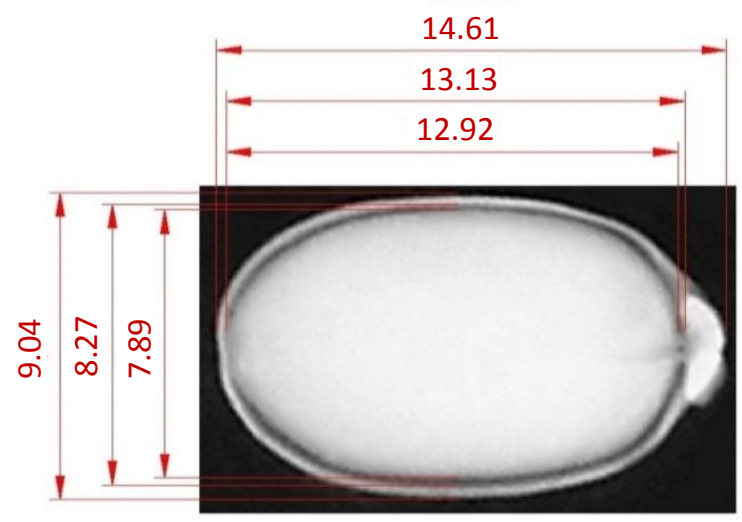

FIGURE 3. Castor bean X-ray with the estimated average dimensions (mm) illustrating the gap (shadowy area) between the endosperm and bean coat (adapted from CARVALHO et al., 2010).

This X-ray of the castor bean (CARVALHO et al., 2010) was used to estimate the size of the endosperm and the bean coat using the average values for width and length of the grain putting the image in scale and considering a castor grain with no physiological problems.

Similar values for strain and maximum rupture force were found by OLAOYE (2000) for castor beans 'Asbowu', 'Evahura' and 'Ojji', all of Nigerian origin. GONELI (2008) found strain values between 12.31 and $19.68 \%$, for height or resting direction, higher than the values found for the length and width positions in this experiment, showing anisotropic behavior in the three orthogonal directions for the rupture of the castor beans bean coat. The values found by the author are relatively high, showing that efforts in the height or resting would not be suitable for proper decortication to obtain the whole endosperm.

Stiffness. Table 5 shows the values of stiffness length and widthwise as affected by drying treatments. It is an important property in designing hulling machines, since estimations of force and strain variations to be imposed on the product are possible.

TABLE 5. Average stiffness values $\left(\mathrm{N} \mathrm{mm}^{-1}\right)$ obtained in the compression tests length and widthwise with the respective coefficients of variation $(\mathrm{CV})$.

\begin{tabular}{lllll}
\hline Drying treatment & Direction & & & \\
\cline { 2 - 5 } & Length & CV $(\%)$ & Width & CV(\%) \\
\hline Farmyard & 100.62 & 13.08 & 70.50 & 11.08 \\
\hline $40^{\circ} \mathrm{C}$ & $\mathrm{A} / \mathrm{a}$ & 15.62 & $\mathrm{~A} / \mathrm{b}$ & 12.61 \\
\hline $60^{\circ} \mathrm{C}$ & 93.38 & 63.99 & $\mathrm{CD} / \mathrm{b}$ & 14.39 \\
\hline $80^{\circ} \mathrm{C}$ & $\mathrm{B} / \mathrm{a}$ & 16.80 & 62.11 & 13.51 \\
\hline $100^{\circ} \mathrm{C}$ & 93.29 & $\mathrm{D} / \mathrm{b}$ & 65.29 \\
\hline Global average & $\mathrm{B} / \mathrm{a}$ & 15.42 & $\mathrm{CB} / \mathrm{b}$ & 13.88 \\
\hline Ava & 96.36 & 17.36 & 67.75 & 13.73 \\
\hline
\end{tabular}

Averages followed by the same capital letter in the column do not differ statistically from each other (Duncan, $\mathrm{p}<0.05$ ). Averages followed by the same letter in the line do not differ statistically from each other (Duncan, $\mathrm{p}<0.05$ ). 
Finally, as they were expected to, the average stiffness values behaved similarly to those of strain, showing the anisotropic behavior between the directions along the length and width, but not discriminating the drying treatments. These values also corroborate with the strain values, since the highest stiffness accompany the smallest strain values. Stiffness showed the lowest coefficients of variation when compared to the other parameters.

Lengthwise the farmyard treatment value obtained was statistically different from treatments 40 and $60^{\circ} \mathrm{C}$. Widthwise, the $60^{\circ} \mathrm{C}$ and farmyard drying treatments are statistically different, being the highest and lowest stiffness values, respectively. The other drying treatments are statistically equal. The coefficients of variation of stiffness values widthwise exhibit the lowest variability among those parameters determined in compression tests, namely maximum rupture force, deformation energy at rupture and strain. The stiffness values were calculated from the values of maximum force and corresponding strain, and showed that the correlation of these parameters represented a decrease in variability (Table 2). This indicates that this parameter has the potential to be used in designing of sizing and hulling mechanisms, together with strain values.

Average stiffness values, regardless the heat treatment, are larger lengthwise. GONELI (2008) found lower and intermediate castor beans stiffness values thickness wise, ranging from 48.18 to $77.82 \mathrm{~N} \mathrm{~mm}^{-1}$, for water content of 8 to $66 \%(\mathrm{db})$, and, therefore, confirming the anisotropic behavior for stiffness in the three orthogonal directions, as previously mentioned. SIRISOMBOON et al. (2007) found similar stiffness values for Jatropha beans.

\section{CONCLUSIONS}

It was concluded that forced air conditioning, more costly than farmyard conditioning, does not bring benefits to decortication. However, regardless of the heat treatment, the mechanical stress of the grain in the longitudinal direction is the most suitable to promote decortication. It was also found that the endosperm of the castor bean contributes to the strength of the bean coat, since the strain value required to disrupt the coat is higher than the estimated gap existing between them. As the compression tests were performed at a strain rate of $0.6 \mathrm{~mm} \mathrm{~s}^{-1}$, a low value compared to the strain rates developed in commercial shelling mechanisms, the application of high strain rates may display even lower values of rupture strain, due to the viscoelastic properties of the grain.

\section{ACKNOWLEDGMENTS}

The authors thank FEAGRI / UNICAMP, CNPq and IAC / APTA.

\section{REFERENCES}

ARAÚJO, M. C.; FERRAZ, A. C. O. Efeito da umidificação, tratamento térmico e deformação sobre a decorticação da castanha de caju 'CCP 76' por meio de impacto único e direcionado. Engenharia Agrícola, Jaboticabal, v. 26, p. 335-653, 2006.

ARAÚJO, M.C.; FERRAZ, A.C.O. Características físicas e mecânicas do endocarpo e da amêndoa da castanha de caju "CCP 76" antes e após tratamento térmico. Engenharia Agrícola, Jaboticabal, v. 28, n.3, p. 565-578, 2008.

BRASIL. Ministério da Agricultura, Pecuária e Abastecimento. Regras para análise de sementes. Brasília: Secretaria de Defesa Agropecuária. 2009.

CARVALHO, M. L. M.; ALVES, R. A.; OLIVEIRA, L. M. Radiographic analysis in castor bean beans (Ricinus communis L.). Revista brasileira de sementes, Viçosa, MG, v.32, n.1, p. 170-175, 2010 .

GONELI, A. L. D.; CORRÊA, P. C.; MAGALHÃES, F. E. de A.; BAPTESTINI, F. M. Contração volumétrica e forma dos frutos de mamona durante a secagem. Acta Scentiarum Agronomy, Maringá, v. 33, n. 1, 2011. 
GONELI, A. L. D.; CORRÊA, P. C.; BOTELHO, F. M.; OLIVEIRA, G. H. H. de; SANTOS, E. de S. Propriedades físicas dos frutos de mamona durante a secagem. Revista Brasileira de Armazenamento, Viçosa, MG, v. 33, p. 148-155, 2008.

GONELI, A.L.D. Variação das propriedades físico-mecânicas e da qualidade da mamona (Ricinus communis L.) durante a secagem e o armazenamento. 2008. 199f. Tese (Doutorado), Universidade Federal de Viçosa, Viçosa, 2008.

GUPTA, R. K.; DAS, S. K. Fracture resistance of sunflower bean and kernel to compressive loading, Journal of Food Engineering, Essex, v. 46, n. 1, p. 1-8, 2000.

MOHSENIN, N. N. Physical properties of plant and animal materials. New York: Gordon and Breach Publishers, 1986. 841 p.

OLAOYE, O.J. Some physical properties of Castor Nut relevant to the design of processing equipment. Journal of Agricultural Engineering Research, London, v.77, p. 113-118, 2000.

PLIESTIC, S.; DOBRICEVIC, N.; FILIPOVIC, D.; GOSPODARIC, Z.. Physical Properties of Filbert Nut and Kernel. Biosystems Engineering, London, v. 93, Issue 2, p. 173-178, 2006.

RESENDE, O.; CORRÊA, P. C.; RIBEIRO, D. M.; FIGUEIREDO NETO, A. Comportamento mecânico dos grãos de feijão submetidos a compressão. Revista Brasileira de Engenharia Agrícola e Ambiental, Campina Grande, v.11, n.4, p. 404-409, 2007.

RIBEIRO, D. M.; CORRÊA, P. C.; FURTADO, B. F.; GONELI, A. L. D.; Resende, Osvaldo Propriedades mecânicas dos grãos de soja em função do teor de água. Engenharia Agrícola, Jaboticabal, v.27, n.2, p. 493-500, 2007.

RITTNER, H. Óleo de mamona e derivados. Editado pelo autor. 1996.

SIRISOMBOON, P.; KITCHAIYA, P.; PHOLPHO, T.; MAHUTTANYAVANITCH, W. Physical and mechanical properties of Jatropha curcas L. fruits, nuts and kernels. Biosystems Engineering, London, v. 97, Issue 2, p. 201-207, 2007. 